\title{
Die popularisering van die wetenskappe
}

Die Republiek van Suid-Afrika het tans ' $n$ nypende tekort aan goed gekwalifiseerde wiskundiges en natuurwetenskaplikes. Skokkende statistieke in dié verband word van tyd tot tyd gepubliseer. Dat die Republiek nie naastenby genoeg wetenskaplikes produseer om in sy eie behoeftes te voorsien nie blyk uit die groot aantal buitelandse wetenskaplikes wat tans hier werksaam is. Of ons ook in die toekoms op hierdie ingevoerde kundigheid sal kan staat maak, sal slegs die tyd leer. Afgesien van die wiskundiges en natuurwetenskaplikes wat nodig is om die Republiek in tred te laat bly met tegnologiese ontwikkelings in die buiteland, is mense ook nodig om op die plaaslike front te werk. Om te oorleef is dit nodig om plaaslike hulpbronne tot die uiterste te benut. Uitgebreide navorsingsprogramme is hiervoor nodig.

Oor moontlike redes vir die tekort aan wetenskaplikes is al baie bespiegel. Die feit van die saak is dat min skoliere belangstel in die beroep van wiskundige of natuurwetenskaplike: Die honderd toppresteerders in die Nasionale Wetenskapolimpiade vir die jeug word jaarliks in Johannesburg saamgetrek om nader met die natuurwetenskappe kennis te maak. Daar mag sekerlik aangeneem word dat hierdie leerlinge 'n natuurlike aanvoeling vir die wetenskappe het. Oor die afgelope vyf jaar het nie een van hierdie leerlinge belangstelling in chemikus as beroep getoon nie, en dit uit 'n groep van 500 potensieel voortreflike wetenskaplikes! Daar kan alleen maar gespekuleer word of goeie voorligting en oriëntasie op 'n vroeë ouderdom dalk ' $n$ invloed op sommige van hierdie leerlinge se besluit sou gehad het.

Om die huidige krisis die hoof te bied, is dit nodig dat die owerheid die inisiatief neem. 'n Deeglike ondersoek in dié verband het sekerlik meriete. So 'n ondersoek kan moontlike redes vir die gebrek aan belangstelling van leerlinge in die natuurwetenskappe uitlig. Dit kan as wegspringplek dien om die saak reg te stel.

Een van die aanbevelings van so ' $n$ ondersoek sal waarskynlik wees dat 'n Sentrum vir die Bevordering van die Natuurwetenskappe ingestel word. Intensiewe veldtogte vir die bekendstelling en popularisering van Wiskunde en die natuurwetenskappe kan uit so 'n sentrum geadministreer word. Verskeie instansies, waaronder universiteite en ook die Stigting vir Onderwys, Wetenskap en Tegnologie, doen reeds werk in dié verband. Dit behoort egter uit 'n sentrale plek gekoördineer en uitgebrei te word. Suid-Afrikaanse wetenskaplikes is gretig om inligtingsveldtogte onder skoliere te onderneem, maar 'n sentrale doeltreffende meganisme daarvoor ontbreek tans.

Die voorgestelde ondersoek sal waarskynlik ook bevind dat inligtingsveldtogte nie net tot skoliere beperk moet word nie, maar dat die publiek self meer bewus gemaak moet word van die natuurwetenskappe. Per slot van rekening, indien ouers self goed ingelig is, kan daar uit die huis baie gedoen word om kinders aan te moedig om loopbane as wetenskaplikes te oorweeg.

Die nuusmedia behoort baie meer as tans te doen om die natuurwetenskappe (op 'n populere vlak) aan die publiek bekend te stel. Die geweldige trefkrag wat televisie het, kan ook hiervoor benut word. Met afwagting sal gekyk word of die voorgestelde opvoedkundige televisieprogramme hierdie gaping kan vul.

Tientalle planne kan beraam word om televisie te gebruik in 'n grootskaalse veldtog om die natuurwetenskappe te populariseer:

* Aankoop van bestaande programreekse. 'n Groot aantal uitstekende wetenskapprogramme is in die buiteland beskikbaar.

* Tuisvervaardigde programme waarin die klem val op plaaslike omstandighede.

* 'n Goeie vasvraprogram op televisie is altyd gewild en kan uitgebrei word tot vasvraprogramme (tussen skole) oor Wiskunde en die natuurwetenskappe.

* Demonstrasies en eksperimente op die skerm, met 'n handleiding en die nodige apparaat te koop, sodat die kyker dit tuis kan doen.

* Meer wetenskaplike nuusdekking oor aktuele sake (bv. die onlangse salmonellageval) en onderhoude met wetenskaplikes wat daarop ingaan.

* Onderhoude met besoekende wetenskaplikes.

* Onderhoude in gespreksprogramme met Suid-Afrikaanse wetenskaplikes. Ons land het verskeie wetenskaplikes wat wêreldberoemdheid verwerf het, maar min mense weet van hulle.

Dit is nie slegs televisie wat in so ' $n$ veldtog betrek moet word nie. Die rol van dagblaaie moet nie onderskat word nie. In 'n opname wat in 1974 in Kanada onder lesers gedoen is, het $82 \%$ van die ondervraag- des gevoel dat wetenskaplike nuusdekking in koerante nodig is. Daar is sekerlik in ons land ook ' $n$ behoefte aan ' $n$ wetenskaprubriek in koerante, bv. 'n tweeweeklikse atlas van sterre en planete.

Die S.A. Akademie se Wiskunde-olimpiade asook die Nasionale Wetenskapolimpiade vir die jeug, met opvolgaksies wat daaruit voortspruit, lok jaarliks groot belangstelling uit by skoliere. Hierdie olimpiade is egter toegespits op senior skoliere. Opvoedkundiges is dit daaroor eens dat die meeste kinders in die senior klasse op hoërskool reeds hul loopbaankeuses gemaak het. As ons deur middel van olimpiades skoliere na Wiskunde en die natuurwetenskap- 
pe wil lok, is dit nodig om derglike olimpiades ook op juniorvlak in te stel. Sulke junior olimpiades word reeds in geïsoleerde gevalle aangebied.

Die gedagtes wat hierbo uitgespreek is, is nie nuut nie. Verskeie ondersoeke is ook al in dié verband gedoen, maar 'n gebrek aan koördinasie het tot gevolg gehad dat voorstelle in die niet verdwyn het. Die stig- ting van 'n Sentrum vir die Bevordering van die Natuurwetenskappe is ook al bepleit in 'n memorandum wat in 1982 voor die Gesamentlike Raad van Natuurwetenskaplike Verenigings gedien het. Die vraag is, wat gaan daaraan gedoen word?

M.J. Schoeman 